\title{
Efficacy of dairy on-farm high-temperature, short-time pasteurization of milk on the viability of Mycobacterium avium ssp. paratuberculosis
}

\author{
Kim Fechner, ${ }^{*}$ Nico Dreymann, ${ }^{*} \dagger$ Sebastian Schimkowiak, Claus-Peter Czerny,‡ and Jenny Teitzel§ $\left({ }^{\circ}\right.$ \\ Division of Microbiology and Animal Hygiene, Department of Animal Sciences, Faculty of Agricultural Sciences, University of Göttingen, \\ 37077 Germany
}

\section{ABSTRACT}

Feeding pasteurized milk to suckling calves is a popular practice used increasingly on dairy farms. Waste milk is frequently fed to calves because of its high nutritional value and economic benefits compared to milk replacement products. However, one of the disadvantages of feeding waste milk is the potential for exposure to a high number of bacterial contaminants, which may lead to serious illnesses or infections in calves. One of these contaminants is Mycobacterium avium ssp. paratuberculosis (MAP), the causative agent of Johne's disease (paratuberculosis). The transmission and distribution of paratuberculosis in dairy herds occurs mostly through the feeding newborn calves with contaminated colostrum or milk, because this age group is believed to be most susceptible to infection. To reduce the risk of transmission of pathogens, on-farm pasteurization of milk has become increasingly popular. In this study, we analyzed the efficacy of a new commercial high-temperature, short-time pasteurizer $\left(73.5^{\circ} \mathrm{C}\right.$ for 20 to $25 \mathrm{~s}$ ) in terms of MAP inactivation under experimental on-farm conditions. The pasteurizer uses a newly developed steam-heating technique, allowing for the pasteurization of the transition milk without clumping. In 3 independent trials, we spiked fresh raw milk samples to a level of $10^{7}$ or $10^{4}$ viable MAP cells/ $\mathrm{mL}$ before pasteurization. We examined the thermal inactivation and viability of MAP using culture and a D29 bacteriophage-based assay. To verify the identity and number of MAP cells, we also performed PCR assays. Pasteurization of the inoculated milk $\left(10^{7}\right.$ and $10^{4}$ MAP cells $/ \mathrm{mL}$ ) resulted in a remarkable reduction in viable MAP cells. The mean inactivation rate of MAP

\footnotetext{
Received March 8, 2019.

Accepted August 15, 2019.

*These authors contributed equally to this work.

†Current address: Fraunhofer Institute for Cell Therapy and Immunology, Branch Bioanalytics and Bioprocesses, Potsdam, Germany.

$\ddagger$ Deceased.

§Corresponding author: JenSch318@gmx.de
}

ranged from 0.82 to $2.65 \log _{10}$ plaque-forming units/ $\mathrm{mL}$, depending on the initial MAP amount inoculated and the addition of conservative agents to the pasteurized milk. Nevertheless, approximately $10^{3}$ MAP cells/ $\mathrm{mL}$ remained viable and could be transferred to calves after high-temperature, short-time pasteurization of milk.

Key words: Mycobacterium avium ssp. paratuberculosis, pasteurization, phage assay, waste milk

\section{INTRODUCTION}

Since the 19th century, pasteurization has been the standard method used to preserve milk for human consumption. This thermal procedure inactivates most pathogenic microorganisms, preventing the oral transmission of milk-borne diseases. In addition, pasteurization increases the shelf life of milk by inactivating spoilage organisms while maintaining the original characteristics and properties of milk and milk products (Holsinger et al., 1997). Alongside the pasteurization of milk for human consumption, the feeding of milk pasteurized on-farm to calves has become increasingly popular. Because of the economic benefits, non-saleable milk, so-called waste milk, is often fed to suckling calves (Stabel et al., 2004), although it presents an increased potential risk of infection. Waste milk is milk that cannot be used for human consumption for various reasons: for example, colostral milk, milk from cows with mastitis, milk from animals undergoing medical treatment, or milk with high SCC content (Aust et al., 2013). These types of milk contain valuable nutrients for suckling calves but are often contaminated with bacteria that may be pathogenic for the calves and their naive immune systems (Selim and Cullor, 1997). Bacterial contamination of milk is caused predominantly by direct shedding of pathogenic microorganisms from dairy cows through the udder, or by contact with pathogens from the environment (e.g., fecal contamination; Oliver et al., 2005). One of the most important pathogens for calves is Mycobacterium avium ssp. paratuberculosis (MAP), which can be transmitted by contaminated 
milk and causes Johne's disease (paratuberculosis). Infection with MAP results in severe enteritis, profuse diarrhea, and progressive weight loss, not in calves but in adult ruminants (Harris and Barletta, 2001). Although symptoms may appear at a later stage, reduced milk production and decreased fertility among dairy cows at the subclinical stage of MAP infection also have a substantial economic impact on the dairy industry (Raizman et al., 2009), in addition to premature culling. Neonatal calves are affected mostly by transmission through colostrum and milk from infected cows (Taylor et al., 1981; Streeter et al., 1995), or from milk or colostrum contaminated with MAP-containing feces (Rademaker et al., 2007). However, feeding calves with pasteurized milk reduces the risk of infection and is suggested to have an immensely positive impact on the health status of suckling calves compared to nonpasteurized milk or milk replacer (Jamaluddin et al., 1996; Godden et al., 2005). To evaluate the efficacy of thermal MAP inactivation in raw milk, we investigated a new on-farm HTST pasteurizer. Its crucial technical difference compared with existing on-farm milk pasteurizers is its newly developed steam-heating system, which enables the pasteurization of transition milk. Under experimental on-farm conditions, fresh raw, bulk milk was inoculated to levels of $10^{7}$ and $10^{4}$ MAP cells/ $\mathrm{mL}$. To determine the viability of MAP before and after pasteurization of the inoculated milk, and also in the machine's rinsing and washing water, we carried out culture-based procedures, a phage-based assay, and PCR assays. We performed the present study to investigate the reduction of viable MAP cells by pasteurization as a way of preventing the transmission of paratuberculosis to calves consuming waste milk.

\section{MATERIALS AND METHODS}

\section{Study Design and Sample Preparation}

Between the end of July and the beginning of November 2017, we obtained fresh raw bulk milk from a local dairy farm directly after machine milking of midlactation animals in the morning (before transfer to milk tanks used for human consumption). The milk was then transported to the Institute of Microbiology and Animal Hygiene (Göttingen, Germany) under uncooled conditions to resemble on-farm circumstances (duration of approximately $20 \mathrm{~min}$ ). The farm's MAP status prior to milk sampling was unknown. The farm houses more than 100 dairy cows, which are milked using a parlor system. The udders of the animals were wiped before milking. The on-farm pasteurizer (HT250; Martin Förster GmbH, Engen, Germany) was placed in an experimental animal stable belonging to the division of
Microbiology and Animal Hygiene (University of Göttingen, Germany). The machine is licensed to prepare milk for calf feeding only, not for human consumption, because a small amount of steamed water is mixed with the milk during pasteurization. The pasteurizer performs continuous-flow milk pasteurization using an HTST method, so that the milk can be directly transferred to the calf feeder. In detail, the inoculated milk was heated by the heat exchanger to 50 to $60^{\circ} \mathrm{C}$, pasteurized with steam at $73.5^{\circ} \mathrm{C}$ for 20 to $25 \mathrm{~s}$, and immediately cooled by the heat exchanger to $40^{\circ} \mathrm{C}$. Three independent trials for inoculated milk were carried out for all experiments. For each trial, $40 \mathrm{~L}$ of raw milk were collected in $50 \mathrm{~L}$ sterile plastic containers. Then, 2 $\mathrm{L}$ of fresh raw bulk milk was taken to analyze the characteristics of the original milk from the farm (sample M). Then, $28 \mathrm{~L}$ of the raw milk was spiked with MAP to a final amount of $10^{7}$ or $10^{4}$ cells $/ \mathrm{mL}$ (sample $\mathbf{M}+; 2$ $\mathrm{L}$ of the inoculated milk was also taken for analysis), as described below. Containers were shaken thoroughly to evenly distribute the MAP in the milk. To ensure that no stagnant water was mixed with the milk samples to be analyzed after pasteurization, a milk volume of $12 \mathrm{~L}$ was required for pasteurization, because the pasteurizer has a flow-through capacity of 5 to 6 L. Then, each 12 $\mathrm{L}$ of inoculated milk was pasteurized (sample $\mathbf{P}$ ). Then, another $12 \mathrm{~L}$ of spiked milk was pasteurized, but this time, a conservation agent (Bergo Stabilomix S; Bergophor Futtermittelfabrik Dr. Berger, Kulmbach, Germany) was automatically added after pasteurization at a concentration of approximately $2 \mathrm{~mL} / \mathrm{L}$ (sample $\mathbf{C}$ ). Conservative agents are often used to stabilize milk and increase its durability. In each trial, 10 of the $40 \mathrm{~L}$ milk was left over and used as retention samples.

After each pasteurization process, the pasteurizer performed a rinsing step using tap water (sample $\mathbf{R}$ ). Rinsing took $6 \mathrm{~min}$ and used approximately $5 \mathrm{~L}$ of tap water per minute. Next, thorough cleaning was performed using $150 \mathrm{~mL}$ of detergent (HyClean A70 Pasteurizer Detergent; Förster-Technik GmbH, Engen, Germany). During this step, the machine was rinsed continuously with a disinfecting detergent for $15 \mathrm{~min}$ and then a further 15 min with tap water (sample $\mathbf{W}$ ). For analysis of the milk samples $(\mathrm{M}, \mathrm{M}+, \mathrm{P}, \mathrm{C})$ or water samples $(\mathrm{R}, \mathrm{W}), 2 \mathrm{~L}$ were collected in sterile glass bottles. All samples were analyzed on the day of collection. To ensure proper handling, conserving, and washing processes, we measured the temperature and $\mathrm{pH}$ values of all samples obtained from the first experiment (3 independent trials with milk spiked with $10^{7} \mathrm{MAP}$ cells $/ \mathrm{mL}$ ). The $\mathrm{pH}$ value of $\mathrm{M}+$ was not measured to prevent contamination of the $\mathrm{pH}$ meter. We also evaluated the pasteurization of all samples by testing the activity of alkaline phosphatase using the Lactognost 
test (HEYL Chemisch-pharmazeutische Fabrik GmbH and Co. KG, Berlin, Germany) and peroxidase using the MQuant test (Merck KGaA, Darmstadt, Germany). Both enzymes are known to occur naturally in milk and have different heat stabilities. The absence of alkaline phosphatase activity indicates pasteurization conditions above $72^{\circ} \mathrm{C}$ for $16 \mathrm{~s}$; the presence of peroxidase confirms conditions below $80^{\circ} \mathrm{C}$ (Rampling et al., 2004; Sharma and Rajput, 2014).

We determined the presence of MAP in all samples $(\mathrm{M}, \mathrm{M}+, \mathrm{P}, \mathrm{C}, \mathrm{R}, \mathrm{W})$ derived from milk spiked with $10^{7}$ or $10^{4}$ cells $/ \mathrm{mL}$ by culture, D29 bacteriophage-based assay, and real-time quantitative PCR (qPCR). All experiments were performed in the laboratory of the division of Microbiology and Animal Hygiene (University of Göttingen), accredited according to the standard DIN EN ISO/IEC 17025:2005.

\section{Inoculation of Raw Milk}

Raw milk was spiked with MAP to final amounts of $10^{7}$ and $10^{4}$ cells $/ \mathrm{mL}$ to imitate concentrations of MAP likely to occur in practice. The MAP reference strain we used (DSMZ ID 44133, Type-II) was from the Leibniz Institute DSMZ German Collection of Microorganisms and Cell Cultures (Braunschweig, Germany). It was cultured in BD Difco Middlebrook 7H9 Broth containing 10\% BD BBL Middlebrook OADC Enrichment (BD, Heidelberg, Germany), 0.2\% glycerin (Carl Roth GmbH and Co. KG, Karlsruhe, Germany), and $2 \mu \mathrm{g} / \mathrm{mL}$ Mycobactin J (ID.vet, Grabels, France). The MAP was grown for 4 to 6 wk at $37^{\circ} \mathrm{C}$ under aerobic conditions in a shaker incubator at $100 \mathrm{rpm}$. For inoculation of the raw milk, the MAP culture solution was ultrasonicated twice for $2 \mathrm{~min}$ at $20 \mathrm{kHz}$ (Sonoplus HD 2200; Bandelin Electronic GmbH and Co. KG, Berlin, Germany) to overcome bacterial clumps and adjusted to $10^{9}$ or $10^{7}$ MAP cells $/ \mathrm{mL}$ by optical density measurement (BioPhotometer; Eppendorf AG, Hamburg, Germany) as described by Janagama et al. (2006). In total, we used $280 \mathrm{~mL}$ of the solution containing $10^{9}$ MAP cells/mL to produce inoculated milk containing approximately $10^{7}$ MAP cells $/ \mathrm{mL}$ in $28 \mathrm{~L}$ of raw milk. To obtain milk with $10^{4} \mathrm{MAP}$ cells $/ \mathrm{mL}$, we used $28 \mathrm{~mL}$ of the MAP culture solution containing $10^{7}$ cells $/ \mathrm{mL}$ to inoculate fresh raw milk. Containers were mixed by shaking, and pasteurization was started immediately.

\section{Detection of Viable MAP by Culture}

All samples (M, M+, P, C, R, W) of both tested concentrations $\left(10^{7}\right.$ and $10^{4}$ MAP cells $\left./ \mathrm{mL}\right)$ were prepared for culture. First, $10 \mathrm{~mL}$ of the samples were suspended in $40 \mathrm{~mL}$ of $0.75 \%$ RonaCare CPC (Merck KGaA, Darmstadt, Germany) for a 1:5 ratio, mixed for $30 \mathrm{~min}$ at $250 \mathrm{rpm}$, and incubated for $24 \mathrm{~h}$ at room temperature. Then, the solutions were centrifuged at 3,000 $\times$ $g$ for $30 \mathrm{~min}$. The supernatant was decanted, and the remaining cell pellet was suspended in $1.25 \mathrm{~mL}$ of $0.9 \%$ sterile $\mathrm{NaCl}$ solution. Each $0.25 \mathrm{~mL}$ of the suspension was cultured on 3 Herrold's egg yolk medium (HEYM) slants. Preparation of HEYM was in accordance with the official manual of diagnostic procedures published by the Friedrich-Loeffler-Institut of the German Federal Research Institute of Animal Health (FriedrichLoeffler-Institut, 2014). The inoculated HEYM slants were incubated at $37^{\circ} \mathrm{C}$. After $4 \mathrm{wk}$, bacterial growth was monitored for the first time and then regularly for up to $16 \mathrm{wk}$. Growth of MAP was verified by a MAPspecific semi-nested PCR (snPCR) as described below.

\section{Detection of Viable MAP by D29 Bacteriophage-Based Assay}

We also conducted D29 bacteriophage-based assays according to Foddai et al. (2009). To obtain the detection limit of the D29 bacteriophage-based assay for MAP in milk samples, a decimal dilution series ranging from $10^{8}$ to $10^{0}$ MAP cells $/ \mathrm{mL}$ milk was performed and analyzed. Before the test, $1 \mathrm{~mL}$ of each dilution or 10 $\mathrm{mL}$ of each sample $(\mathrm{M}, \mathrm{M}+, \mathrm{P}, \mathrm{C}, \mathrm{R}, \mathrm{W})$ was centrifuged for $30 \mathrm{~min}$ at $3,000 \times g$. The supernatant was decanted and the remaining cell pellet was resuspended in $1 \mathrm{~mL}$ of a $0.9 \%$ sterile $\mathrm{NaCl}$ solution. Then, $100 \mu \mathrm{L}$ of the D29 bacteriophage suspension containing $10^{10} \mathrm{pfu}$ was added to the samples in each assay. Propagation of the D29 bacteriophage was carried out as described by Foddai et al. (2009). The suspension was incubated for $3 \mathrm{~h}$ at $37^{\circ} \mathrm{C}$ and $100 \mathrm{rpm}$. After the first incubation, the remaining extracellular bacteriophages were inactivated by virucide treatment with $100 \mu \mathrm{L}$ of sterile $100 \mathrm{~m} M$ ammoniumferrous (II) sulfate-hexahydrate for 5 min without shaking, followed by 5 min of inversion. Afterward, the virucide was neutralized by adding 5 $\mathrm{mL}$ of Middlebrook 7H9 Broth medium containing $10 \%$ Middlebrook OADC Enrichment and $2 \mathrm{mM} \mathrm{CaCl}_{2}$. Samples were incubated for $2 \mathrm{~h}$ at $37^{\circ} \mathrm{C}$ under continuous inversion. All suspensions were diluted in decimal dilution series up to $10^{-5}$ in Middlebrook $7 \mathrm{H} 9$ Broth medium. Then, $1 \mathrm{~mL}$ of the suspension, its remaining residue, and $100 \mu \mathrm{L}$ from each dilution were mixed in Petri dishes with $1 \mathrm{~mL}$ of Mycobacterium smegmatis laboratory strain $\left(\mathrm{MC}^{2} 155\right)$ fluid culture, $5 \mathrm{~mL}$ of Middlebrook 7H9 Broth medium containing 10\% Middlebrook OADC Enrichment, $2 \mathrm{mM} \mathrm{CaCl}$, and a further $5 \mathrm{~mL}$ of Middlebrook 7H9 agar. All samples were mixed 
carefully by panning. After cooling for approximately $15 \mathrm{~min}$, the agar plates were incubated at $37^{\circ} \mathrm{C}$ for $24 \mathrm{~h}$.

As positive control, we used a MAP culture solution with approximately $10^{8}$ or $10^{5}$ cells as a reference assay, prepared simultaneously during all assays. We confirmed the functionality of the assay with different control trials; that is, virus activity and inactivation and the activity of $M$. smegmatis $\mathrm{MC}^{2} 155$ as a sensor cell were checked separately in each run. Further, to ensure sterile sample preparation, single nutrition medianutrition media containing only bacteriophages and media mixed with $M$. smegmatis $\mathrm{MC}^{2} 155$ (independent or in combination with virus) were prepared separately for all assays. Plaques (pfu/mL) on agar plates were counted, taking only plates with 5 to 300 plaques into account. Calculation of plaques $[ \pm$ standard deviation (SD)] was carried out based on the assumption that 1 mycobacterial cell in the original sample represented 1 pfu (Foddai et al., 2010). We also calculated the mean reduction from milk spiked with MAP $(\mathrm{M}+)$ to pasteurized milk $(\mathrm{P})$ and from $\mathrm{M}+$ to pasteurized milk with conservative agents $(\mathrm{C})$. The number of bacteria in $\mathrm{M}+, \mathrm{P}$, and $\mathrm{C}$ samples for each trial, as were detected by the D29 phage assay, were logarithmized to base 10 . We calculated the reduction of $\mathrm{pfu} / \mathrm{mL}$ for each trial, and then the mean reduction overall from $\mathrm{M}+$ to $\mathrm{P}$ and $\mathrm{M}+$ to $\mathrm{C}( \pm \mathrm{SD})$. All calculations were performed using Excel (Microsoft, Redmond, WA).

To exclude the detection of other mycobacteria in milk samples before inoculation of MAP (M), we performed a Mycobacterium avium complex multiplex PCR of the DNA extracted from the plaques or agar pieces as described below.

\section{Detection of MAP by Quantitative Real-Time PCR}

For qPCR analysis, we extracted DNA from each sample $(\mathrm{M}, \mathrm{M}+, \mathrm{P}, \mathrm{C}, \mathrm{R}$, and $\mathrm{W}$ derived from milk spiked with of both MAP contents of $10^{7}$ and $10^{4}$ cells/ $\mathrm{mL}$ ) using a modified protocol from the InnuPREP MP Basic Kit A (Analytik Jena AG, Jena, Germany). First, $10 \mathrm{~mL}$ of each sample was centrifuged at $3,000 \times g$ for $30 \mathrm{~min}$. The supernatant was decanted, and the cell pellet resuspended in $1 \mathrm{~mL}$ of $0.9 \% \mathrm{NaCl}$ solution. Each sample was ultrasonicated twice for 2 min at $20 \mathrm{kHz}$ and transferred to a Precellys tube (Soil grinding SK38, Precellys Lysing Kit; Bertin Instruments, Montigny-leBretonneux, France). Then, $250 \mu \mathrm{L}$ of MagNA Pure Bacteria Lysis Buffer (Roche Molecular Diagnostics, Pleasanton, CA) was added and the samples were homogenized at $6,500 \mathrm{rpm}$ for $30 \mathrm{~s}$ in a Precellys 24 homogenizer (Bertin Instruments). After mixing with 60 $\mu \mathrm{L}$ of proteinase $\mathrm{K}$ solution $(20 \mathrm{mg} / \mathrm{mL}$; Carl Roth $\mathrm{GmbH}+\mathrm{Co} . \mathrm{KG})$, the samples were incubated in a shaker at $900 \mathrm{rpm}$ and $56^{\circ} \mathrm{C}$ for $60 \mathrm{~min}$ (Bioer Mixing Block MB- 102; Bioer Technology, Hangzhou, China). Samples were transferred into new sterile tubes, 450 $\mu \mathrm{L}$ of Lysis Solution RL were added, and then the samples were mixed and incubated for $15 \mathrm{~min}$ at room temperature with continuous shaking at $250 \mathrm{rpm}$ on a thermomixer. The suspension was centrifuged briefly before the supernatants were transferred into new tubes and $450 \mu \mathrm{L}$ of Binding Solution B and $20 \mu \mathrm{L}$ of MAG Suspension M were added. Next, the suspensions were mixed, incubated for $5 \mathrm{~min}$ at room temperature, and washed according to the kit manual. The DNA samples were eluted with $100 \mu \mathrm{L}$ of DNase-free and RNase-free water and stored at $-80^{\circ} \mathrm{C}$ before use. In each DNA extraction, we included a negative control of $1 \mathrm{~mL}$ of sterile $0.9 \% \mathrm{NaCl}$ solution and a positive control of 1 $\mathrm{mL}$ of pure MAP culture (DSMZ ID 44133) with a content of $10^{8}$ cells $/ \mathrm{mL}$.

The qPCR was performed as described by Fechner et al. (2017). A MAP DNA standard curve (DSMZ ID 44133) was titrated in $\log _{10}$ steps $(1 \mathrm{ng} / \mu \mathrm{L}$ to $1 \mathrm{fg} /$ $\mu \mathrm{L})$ for quantification of MAP DNA concentration, as well as a positive control. We calculated MAP genome equivalents (MAP-GE) detected by qPCR as described elsewhere (Fechner et al., 2017), assuming a DNA concentration of $5.29 \mathrm{fg} / \mathrm{MAP}$ cell. The qPCR had a detection limit of $50 \mathrm{fg} /$ reaction (approximately 10 MAP-GE per reaction) and a quantification limit of $5 \mathrm{pg}$ of MAP DNA per reaction (approximately 950 MAP-GE per reaction; Fechner et al., 2017).

\section{Verification of MAP Growth by Qualitative sNPCR}

Growth of MAP on HEYM slants was verified by snPCR. Pure colonies on the HEYM slants were suspended in $100 \mu \mathrm{L}$ of sterile $0.9 \% \mathrm{NaCl}$ solution and incubated at $100^{\circ} \mathrm{C}$ and $300 \mathrm{rpm}$. After $20 \mathrm{~min}$, the suspensions were centrifuged at $14,000 \times g$ for $10 \mathrm{~min}$, and the supernatants were collected and centrifuged again. The extracted DNA was used as the DNA template. The snPCR was performed as described elsewhere (Münster et al., 2011). We used sterile distilled water as a negative control and extracted MAP DNA $(10 \mathrm{ng} / \mu \mathrm{L}$; DSMZ ID 44133) as a positive control in each PCR run. We carried out DNA isolation, preparation of master mixes, addition of template DNA, and electrophoresis in separate laboratories to avoid cross-contamination.

\section{Verification of MAP in Plaques of the D29 \\ Bacteriophage Assay by M. avium Complex Multiplex PCR}

To exclude the detection of other mycobacteria in milk samples before inoculation with MAP (M), we 
extracted DNA from the center of the plaques using the MiniElute Gel Extraction Kit (Quiagen, Hilden, Germany) after D29 bacteriophage-based assay performance. The DNA was used for $M$. avium complex multiplex PCR as described by Shin et al. (2010). In the case of no plaque formation, agar pieces were controlled equally. M. avium complex multiplex PCR allowed for the differentiation of mycobacteria species. In each PCR run, sterile distilled water was used as a negative control, and $M$. avium ssp. avium DNA extracted from the reference strain DSMZ ID 44156 (Leibniz Institute DSMZ German Collection of Microorganisms and Cell Cultures) was used as a positive control.

\section{RESULTS}

\section{Enzyme Activity, pH Value, and Temperature Tests}

All milk samples (M, M+, P, C) of the 3 trials (12 samples in total) initially spiked with $10^{7}$ MAP cells/ $\mathrm{mL}$ were positive by peroxidase test, and positive by alkaline phosphatase test only in milk samples before pasteurization $(\mathrm{M}, \mathrm{M}+)$. This finding confirmed the proper pasteurization process. The temperature of the milk samples before pasteurization $(\mathrm{M}, \mathrm{M}+$ ) ranged from $24.5^{\circ} \mathrm{C}$ to $30^{\circ} \mathrm{C}$, and the temperature of the milk samples after pasteurization $(\mathrm{P}, \mathrm{C})$, as well as the water samples (R, W) ranged from $43^{\circ} \mathrm{C}$ to $48.5^{\circ} \mathrm{C}$ (Table 1 ). The $\mathrm{pH}$ values of milk that was not inoculated and pasteurized ranged from 6.6 to 6.7 . The $\mathrm{pH}$ values of milk samples with a conservative agent $(\mathrm{C})$ were ap- proximately 6.0. The $\mathrm{pH}$ values of the rinsing water and washing water samples $(\mathrm{R}, \mathrm{W})$ ranged from 7.1 to 7.5 and 12.1 to 12.6 , respectively.

\section{Detection Limit of D29 Bacteriophage-Based Assay in Raw Milk}

We performed a decimal dilution series ranging from $10^{8}$ to $10^{0} \mathrm{MAP}$ cells $/ \mathrm{mL}$ of milk and analyzed it to determine the detection limit of the phage-based assay for milk samples (Figure 1).

In raw milk samples before inoculation with MAP cells, no plaque-forming units were detected, verifying the absence of naturally occurring mycobacteria. In spiked milk samples $\left(10^{8}\right.$ to $10^{0} \mathrm{MAP}$ cells $\left./ \mathrm{mL}\right)$, plaqueforming units were detected up to $10^{2} \mathrm{MAP}$ cells $/ \mathrm{mL}$ of milk. We calculated the MAP content from each dilution in triplicate, assuming that 1 pfu corresponded to 1 MAP cell (Foddai et al., 2010).

\section{Detection of Viable MAP by D29 Bacteriophage-Based Assay}

To detect viable MAP by D29 bacteriophage-based assay, all samples $(\mathrm{M}, \mathrm{M}+, \mathrm{P}, \mathrm{C}, \mathrm{R}, \mathrm{W})$ derived from milk spiked with $10^{7}$ and $10^{4}$ MAP cells $/ \mathrm{mL}$ were analyzed in triplicate and in 3 independent trials (Figures 2 and 3$)$. In 2 raw milk samples before inoculation (M), MAP was detected by D29 bacteriophage-based assay and verified by MAP-PCR. The detected counts of plaque-forming units (pfu; $\pm \mathrm{SD}$ ) were $2.29 \times 10^{3} \pm$

Table 1. Temperature, $\mathrm{pH}$ value, and detection of peroxidase and alkaline phosphatase for each milk sample with an initial number of $10^{7}$ Mycobacterium avium ssp. paratuberculosis cells $/ \mathrm{mL}$ in 3 independent trials (n $=3$ )

\begin{tabular}{|c|c|c|c|c|c|}
\hline Sample ${ }^{1}$ & Trial & $\begin{array}{l}\text { Temperature, } \\
{ }^{\circ} \mathrm{C}( \pm 0.5)\end{array}$ & $\begin{array}{c}\mathrm{pH} \\
( \pm 0.2)\end{array}$ & Peroxidase & $\begin{array}{c}\text { Alkaline } \\
\text { phosphatase }\end{array}$ \\
\hline \multirow[t]{3}{*}{ M } & 1 & 27 & 6.6 & + & + \\
\hline & 2 & 25 & 6.7 & + & + \\
\hline & 3 & 30 & 6.6 & + & + \\
\hline \multirow[t]{3}{*}{$\mathrm{M}+$} & 1 & 26 & - & + & + \\
\hline & 2 & 24.5 & - & + & + \\
\hline & 3 & 28.5 & - & + & + \\
\hline \multirow[t]{3}{*}{$\mathrm{P}$} & 1 & 44 & 6.7 & + & - \\
\hline & 2 & 43 & 6.7 & + & - \\
\hline & 3 & 44.5 & 6.6 & + & - \\
\hline \multirow[t]{3}{*}{ C } & 1 & 43 & 6.0 & + & - \\
\hline & 2 & 43 & 6.0 & + & - \\
\hline & 3 & 43.5 & 5.9 & + & - \\
\hline \multirow[t]{3}{*}{$\mathrm{R}$} & 1 & 45 & 7.4 & - & - \\
\hline & 2 & 44.5 & 7.5 & - & - \\
\hline & 3 & 45 & 7.1 & - & - \\
\hline \multirow[t]{3}{*}{ W } & 1 & 43.5 & 12.6 & - & - \\
\hline & 2 & 48 & 12.2 & - & - \\
\hline & 3 & 48.5 & 12.1 & - & - \\
\hline
\end{tabular}

${ }^{1} \mathrm{M}=$ original raw milk; $\mathrm{M}+=$ artificially spiked milk; $\mathrm{P}=$ pasteurized milk; $\mathrm{C}=$ pasteurized milk containing conservation agent; $\mathrm{R}=$ rinsing water; $\mathrm{W}=$ washing water. 


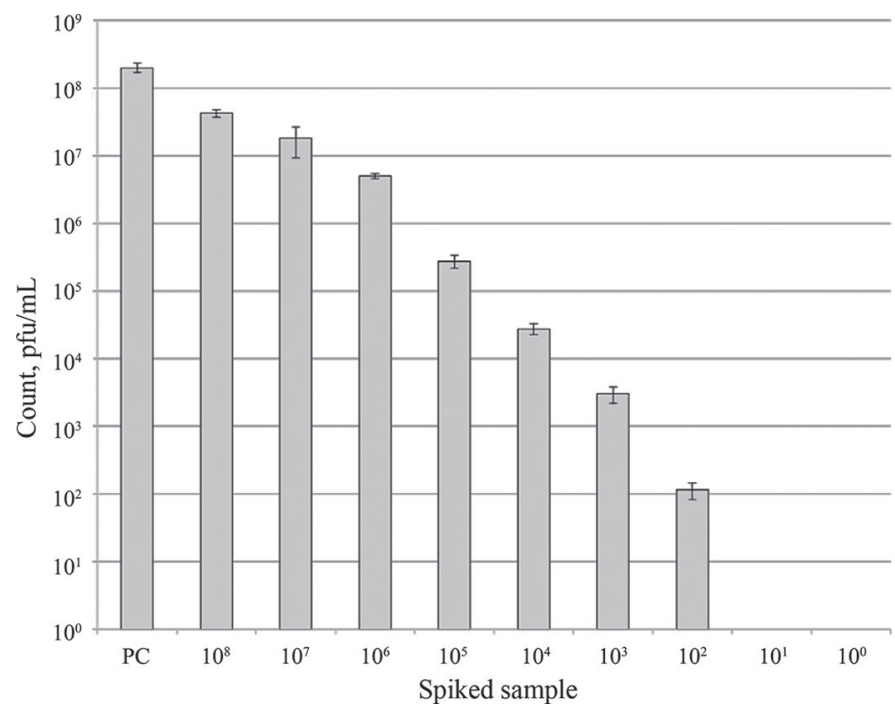

Figure 1. Detection limit of the D29 bacteriophage-based assay in raw milk samples containing artificially spiked Mycobacterium avium ssp. paratuberculosis (MAP) cells in $\log _{10}$ stages from $10^{0}$ to $10^{8}$ per $\mathrm{mL}$. Liquid culture solutions were used as a positive control (PC). Samples were repeated 3 times independently $(\mathrm{n}=3)$. Calculation of MAP was performed, assuming that 1 pfu corresponded to 1 MAP cell. Values are given as means and standard deviations for each sample.
$1.49 \times 10^{3}$ and $2.33 \times 10^{3} \pm 8.22 \times 10^{2} \mathrm{pfu} / \mathrm{mL}$ (Figure 2 ). In all other raw milk samples, we did not observe formation of plaques.

Milk was spiked with MAP to $10^{7} \mathrm{MAP}$ cells $/ \mathrm{mL}$ of milk (Figure 2). The level of plaque-forming units in $\mathrm{M}+$ samples ranged from $1.06 \times 10^{6} \pm 4.06 \times 10^{5}$ to $4.48 \times 10^{6} \pm 4.27 \times 10^{6} \mathrm{pfu} / \mathrm{mL}$. In $\mathrm{P}$ and $\mathrm{C}$ samples, we found MAP amounts of $3.24 \times 10^{3} \pm 9.07 \times 10^{2}$ to $9.73 \times 10^{4} \pm 1.49 \times 10^{4} \mathrm{pfu} / \mathrm{mL}$. The calculated content in rinsing water samples ranged from $3.36 \times 10^{2}$ $\pm 5.4 \times 10^{1}$ to $6.23 \times 10^{2} \pm 1.23 \times 10^{2} \mathrm{pfu} / \mathrm{mL}$. In W samples, values ranged from $7.33 \times 10^{2} \pm 3.7 \times 10^{1}$ to $9.78 \times 10^{3} \pm 7.06 \times 10^{3} \mathrm{pfu} / \mathrm{mL}$. The mean reduction of viable MAP in $\mathrm{P}$ samples was $1.57 \log _{10} \mathrm{pfu} / \mathrm{mL}$, and in $\mathrm{C}$ samples was $2.65 \log _{10} \mathrm{pfu} / \mathrm{mL}$.

We observed the effect of pasteurization on the number of MAP commonly found in raw milk samples from naturally infected cows by reconstructing milk samples with a lower but more realistic level of $10^{4} \mathrm{MAP}$ cells/ $\mathrm{mL}$ milk (Figure 3). In 3 independent trials, the MAP amount in inoculated milk samples $(\mathrm{M}+)$ ranged from $1.53 \times 10^{4} \pm 1.82 \times 10^{3}$ to $2.51 \times 10^{4} \pm 1.23 \times 10^{4} \mathrm{pfu} /$ $\mathrm{mL}$. Following pasteurization $(\mathrm{P})$ and pasteurization with additionally added conservative agent $(\mathrm{C}), 1.09$ $\times 10^{3} \pm 3.1 \times 10^{1}$ to $4.36 \times 10^{3} \pm 3.28 \times 10^{2} \mathrm{pfu} / \mathrm{mL}$

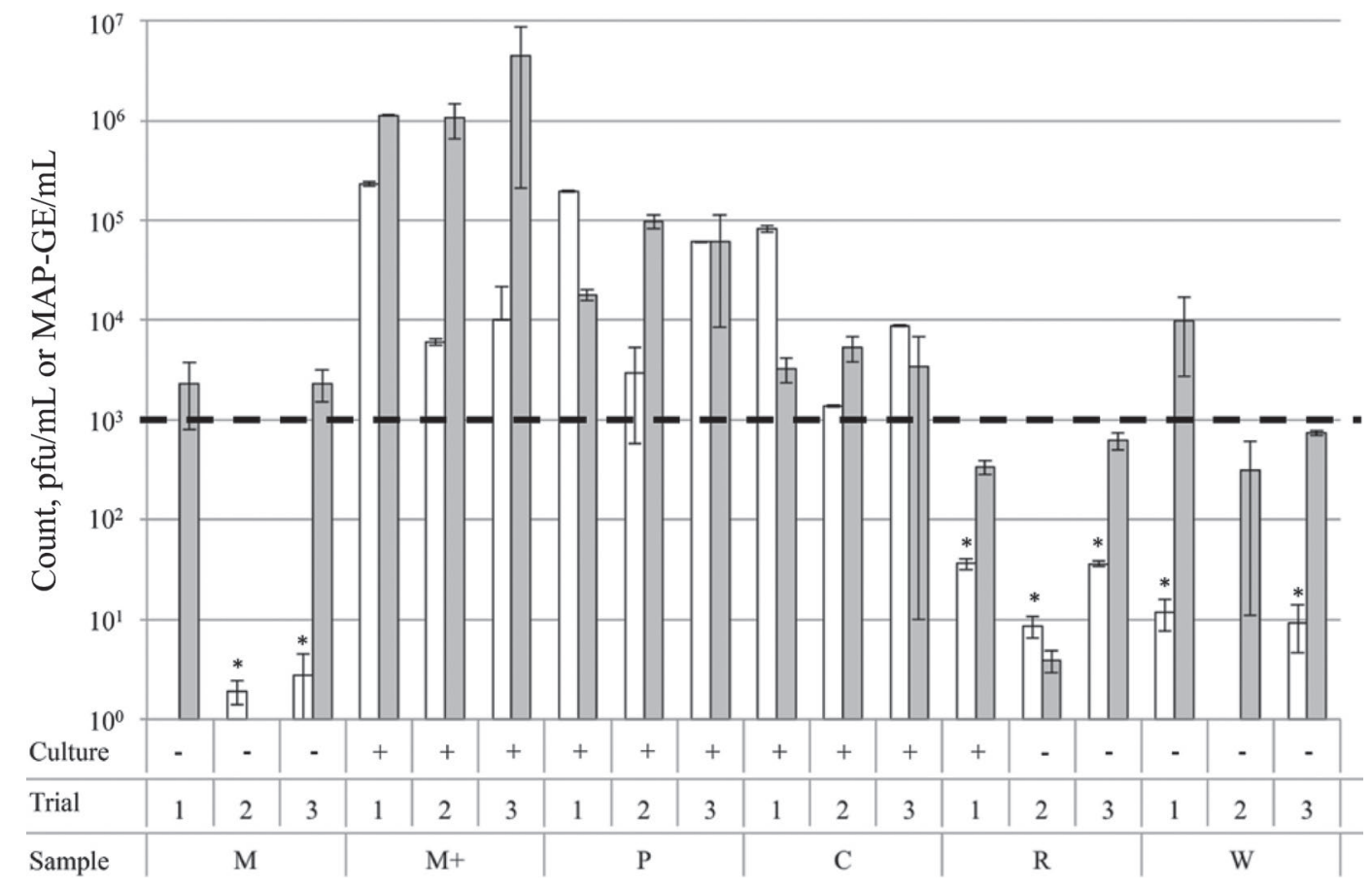

Figure 2. Overview of the detection of Mycobacterium avium ssp. paratuberculosis (MAP) in original raw milk (M), in milk artificially spiked to achieve $10^{7} \mathrm{MAP}$ cells $/ \mathrm{mL}(\mathrm{M}+)$, after pasteurization $(\mathrm{P})$, after pasteurization and conservation $(\mathrm{C})$, and in rinsing $(\mathrm{R})$ and washing water (W) using culture $(+/-)$, phage-based assays (gray bars), and quantitative real-time PCR (white bars). Samples were repeated 3 times independently $(\mathrm{n}=3$ trials). Values are given as mean and standard deviations for each sample. Dashed line indicates the extrapolated MAP genome equivalent (MAP-GE) values below the quantification limit. Asterisks indicate extrapolated values, due to quantification limit. 


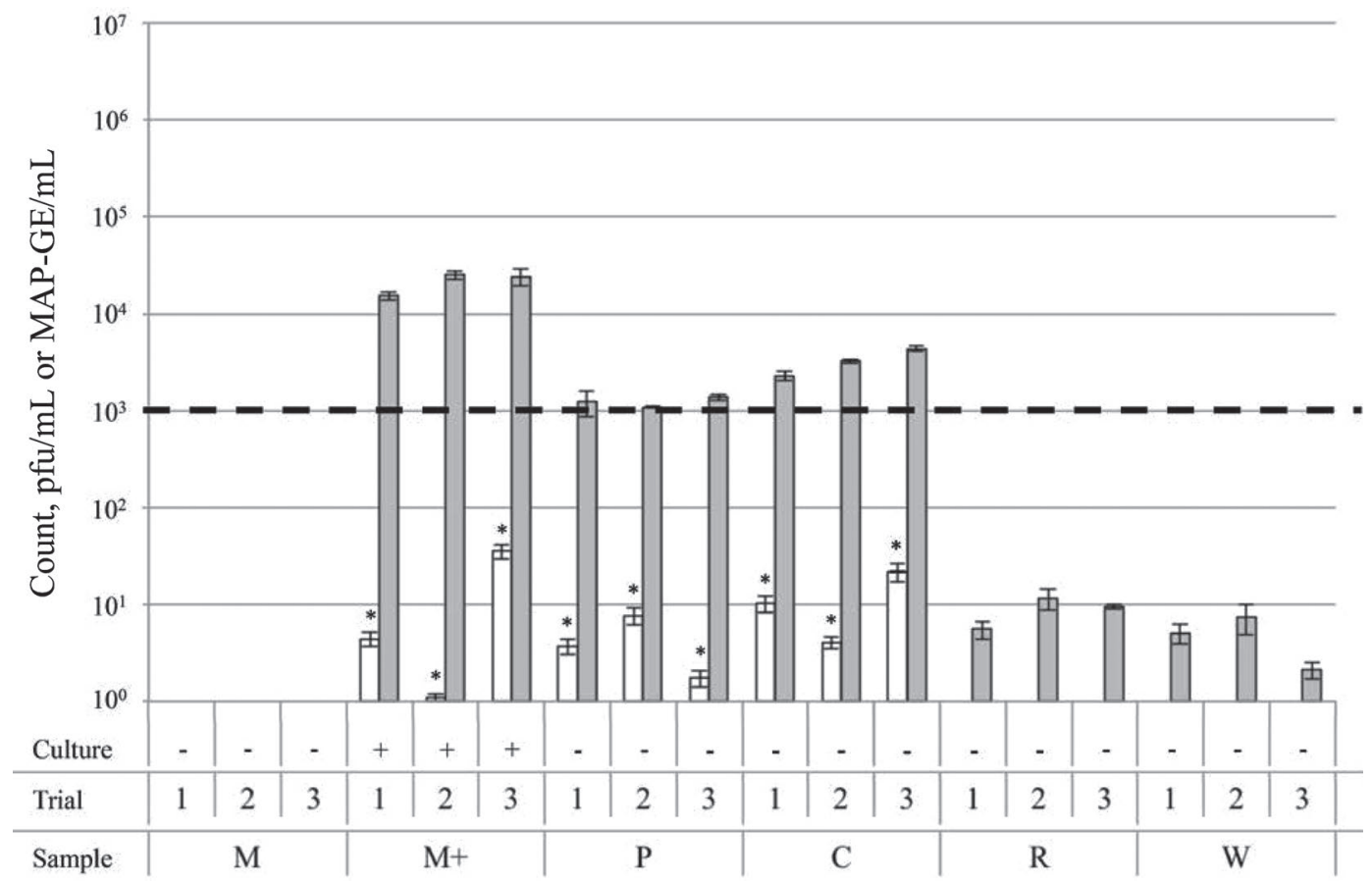

Figure 3. Overview of the detection of Mycobacterium avium ssp. paratuberculosis (MAP) in original raw milk (M), in milk artificially spiked to achieve $10^{4} \mathrm{MAP}$ cells $/ \mathrm{mL}(\mathrm{M}+)$, after pasteurization $(\mathrm{P})$, after pasteurization and conservation $(\mathrm{C})$, and in rinsing $(\mathrm{R})$ and washing water (W) using culture $(+/-)$, phage-based assays (gray bars), and quantitative real-time PCR (white bars). Samples were repeated 3 times independently $(\mathrm{n}=3$ trials). Values are given as mean and standard deviations for each sample. Dashed line indicates the extrapolated MAP genome equivalent (MAP-GE) values below the quantification limit. Asterisks indicate extrapolated values, due to quantification limit.

were detected. In $\mathrm{R}$ and $\mathrm{W}$ samples, we observed values ranging from $2.11 \times 10^{0} \pm 1.00 \times 10^{0}$ to $1.14 \times 10^{1} \pm$ $3.53 \times 10^{0} \mathrm{pfu} / \mathrm{mL}$. The mean reduction of viable MAP in $\mathrm{P}$ samples was $1.24 \log _{10} \mathrm{pfu} / \mathrm{mL}$, and in $\mathrm{C}$ samples was $0.82 \log _{10} \mathrm{pfu} / \mathrm{mL}$.

\section{Culture Investigation}

We did not detect MAP growth by culture in any original raw milk samples before inoculation (M), or in milk spiked with $10^{7} \mathrm{MAP}$ cells $/ \mathrm{mL}$ (Figure 2) or $10^{4}$ MAP cells $/ \mathrm{mL}$ (Figure 3). In all cultures of $\mathrm{M}+$ samples, growth of MAP was confirmed by snPCR. As well, in $\mathrm{P}, \mathrm{C}$, and $\mathrm{R}$ samples, MAP growth was observed. No growth of MAP was observed in any other sample.

\section{Detection of MAP DNA by Quantitative Real-Time PCR}

In addition to the detection of viable MAP by D29 bacteriophage-based assay and culture, we monitored the content of MAP DNA using qPCR. All samples (M, $\mathrm{M}+, \mathrm{P}, \mathrm{C}, \mathrm{R}, \mathrm{W}$ ) of all trials were tested in 3 independent $q \mathrm{PCR}$ runs. Two milk samples before inoculation (M) tested positive for MAP DNA, but because of the quantification limit, we could not quantify MAP-GE exactly; instead, we extrapolated them from the data (Figure 2).

In all 3 milk samples independently inoculated to a final number of $10^{7} \mathrm{MAP}$ cells $/ \mathrm{mL}(\mathrm{M}+$; Figure 2), the recovery rate of MAP-GE ranged from $6.03 \times 10^{3}$ to $2.30 \times 10^{5}$ per $\mathrm{mL}$. The MAP DNA content in $\mathrm{P}$ and $\mathrm{C}$ samples was comparable to amounts detected in $\mathrm{M}+$ samples, and ranged from $2.92 \times 10^{3}$ to 1.96 $\times 10^{5}$ MAP-GE $/ \mathrm{mL}$. All $\mathrm{R}$ samples and $2 \mathrm{~W}$ samples tested positive for MAP DNA. However, MAP genome quantification failed here, because the numbers were below the quantification limit of the qPCR. The $\mathrm{W}$ sample from the second trial tested negative.

All milk and water samples obtained from raw milk with a final number of $10^{4} \mathrm{MAP}$ cells $/ \mathrm{mL}$ were also tested by $\mathrm{qPCR}$ (Figure 3). We found MAP DNA in milk samples $(\mathrm{M}+, \mathrm{P}, \mathrm{C})$, but could not quantify them because of the quantification limit. In all water samples $(\mathrm{R}, \mathrm{W})$ MAP DNA was not detectable.

\section{DISCUSSION}

For farmers, it is of great economic interest to use milk for rearing calves instead of purchasing milk replacers, particularly because the nutritional value of 
milk is higher than that of many milk replacers (Blome et al., 2003). However, the feeding of "waste milk" to young calves puts them at risk of germ transmission and infection. To reduce high bacterial counts, on-farm pasteurization is becoming increasingly popular. In the present study, we investigated the stability of MAP bacteria after HTST pasteurization under experimental on-farm conditions. The data showed that viable MAP cells were detectable in spiked milk after pasteurization and even in the rinsing and washing water of the pasteurizer. In contrast to conventional pasteurization methods, the device we used is based on a recently developed steam-heating system. It prevents clumping during pasteurization of the transition milk. The first colostrum after calving could not be used without technical difficulties.

The literature is contradictory with respect to the efficacy of pasteurization in eradicating MAP from milk samples. Some studies have demonstrated that MAP can survive under simulated pasteurization conditions (Grant et al., 1996; Foddai et al., 2010) or in pasteurized milk or bulk milk samples directly received from dairy farms (Ayele et al., 2005; Ellingson et al., 2005; Gerrard et al., 2018). Other researchers have shown that no viable MAP cells could be detected by culture using commercial on-farm HTST pasteurizers, although that milk contained $10^{2}$ to $10^{6} \mathrm{MAP} / \mathrm{mL}$ before pasteurization (Stabel, 2001; Stabel et al., 2004). These studies differed not only with respect to temperature ranges, time scales, and the way heat was applied, but also in methods used for MAP detection. For the detection of most microorganisms, culture of viable MAP cells is considered the gold standard diagnostic test (Stabel et al., 2002). However, MAP is a slow-growing bacteria with a long generation time (Lambrecht et al., 1988), and the culture period required is up to 16 weeks (Stabel et al., 2002). In addition, overgrowth of cultures by contamination of fungi or competing fast-growing bacteria and necessary sample decontamination further affects the detectability of MAP in culture through the loss of bacterial viability (Bradner et al., 2013). Furthermore, MAP can enter a state of dormancy in which they are viable but non-culturable (Lamont et al., 2012). Therefore, the detection of MAP from animal samples using culture is highly limited. Studies have shown that the detection limit of MAP culture from milk samples is approximately $10^{3}$ MAP cells/g (Messelhäusser et al., 2012). The results of the present study show also that a feasible detection of MAP by culture depends on a minimum number of $10^{3}$ MAP cells $/ \mathrm{mL}$ (Figures 2 and 3). Given these findings, we used an additional D29 bacteriophage-based assay (Foddai et al., 2009) in this study to detect and enumerate viable MAP cells more quickly and efficiently. We observed that the detection limit of the D29 bacteriophage-based assay in milk was approximately $10^{2}$ MAP cells $/ \mathrm{mL}$, suggesting that this assay was more sensitive for detecting viable MAP compared with culture. The specificity of the phage assay is based on subsequent analysis of plaques by specific PCR methods. A recent study (Gerrard et al., 2018) investigated the occurrence of MAP in retail pasteurized milk ( $\mathrm{n}=368)$, using the same phage-based assay. Compared to previous studies, higher percentages of viable MAP cells (10.3\%) were detected by the phage-based assay in the collected samples. This may indicate that the phage-based assay can detect lower numbers of MAP compared to culture and direct PCR (Gerrard et al., 2018). In the present study, we did not observe growth of MAP colonies in any of the original raw milk cultures, but the phage-based assay showed 2 positive results ( $\mathrm{M}$ samples, first and third trial; Figure 2 ). Furthermore, the results of the $\mathrm{qPCR}$, which we performed to detect and calculate MAP-GE, underline the difficulty of detecting MAP at low levels. Although MAP was detectable by qPCR in 2 out of 3 trials in the raw milk (M, second and third trials), the number of MAP-GE in the samples was too low to measure (Figure 2). In the first trial, MAP DNA was not measurable, probably because of inefficient DNA extraction procedures (Mumy and Findlay, 2004). Overall, DNAbased analysis of contaminants in milk is difficult, because milk components such as calcium ions can inhibit the PCR reaction and lead to underestimated recovery rates (Bickley et al., 1996). This factor may also explain the heterologous recovery rates of MAP-GE by qPCR in spiked milk samples $(\mathrm{M}+)$ we found in the present study. Although $\mathrm{qPCR}$ showed a positive result in the original raw milk sample of the second trial $(\mathrm{M})$, viable MAP cells were not detectable in this sample by phage-based assay or culture. However, it is important to bear in mind that PCR does not distinguish between live and dead cells, and culture or phage-based assays detect only viable cells. Considering the results of each method used in the present, it is most likely that the number of viable MAP cells in the original raw milk sample was moderate, ranging between 2 and $10^{3}$ MAP cells $/ \mathrm{mL}$, reaching the detection limit of the methods used.

Besides technical and methodological differences or problems in experimentation, the presence of cell clumps must be considered in relation to MAP detection in pasteurization experiments (Klijn et al., 2001). It has been established that MAP forms clumps containing a high number of cells during growth in culture (Lambrecht et al., 1988) or occurs naturally in fecal samples or contaminated milk (Klijn et al., 2001). This clumping of cells has a great effect on heat resistance through pasteurization and MAP survival (Klijn et al., 
2001). In the present pasteurization study, we observed a mean reduction of $0.82 \log _{10}$ to $2.65 \log _{10} \mathrm{pfu} / \mathrm{mL}$, depending on the initial amount or addition of conservation agent, with the phage-based assay. Independent of the final MAP content before pasteurization $\left(10^{7}\right.$ or $10^{4}$ MAP cells $/ \mathrm{mL}$ ), a minimum number of $10^{3}$ viable MAP cells/mL remained measurable by bacteriophagebased assay. Therefore, we assume that MAP survival is caused by a fraction of clumps additional to the heatresistant single-cell fraction as described by Klijn et al. (2001). Cells inside the clumps may not be inactivated by heating because they are protected by the outer cells of the clumps. In our study, the culture solution was ultrasonicated before milk inoculation to disrupt cell clumps. However, prepared microscopic slides of ultrasonicated MAP culture solution showed that complete disruption of the clumps was not possible by ultrasonication, and that only a reduction of cell clumps was achieved in the current study. Therefore, it is reasonable to conclude that the presence of MAP cell clumps cannot be excluded in our study.

Even if milk was contaminated with a low bacterial dose, MAP survival after a short heat treatment cannot be excluded. At this point, we know little about the minimum oral infective dose of MAP in cattle. Sweeney et al. (2006) demonstrated a successful infection of young calves with a dose of $1.5 \times 10^{6} \mathrm{cfu}$. However, in sheep and red deer, the minimum oral infective dose of MAP is estimated to be approximately $10^{3} \mathrm{cfu}$ (Brotherston et al., 1961; Mackintosh et al., 2007). Therefore, one could presume that milk containing $10^{3}$ MAP cells/mL might also be infectious for dairy calves. In previous studies, MAP was shed at low numbers, of only $2.0 \times 10^{0}$ to $8.0 \times 10^{0} \mathrm{cfu} / 50 \mathrm{~mL}$ (Sweeney et al., $1992)$ and $2.4 \times 10^{1} \pm 1.2 \times 10^{1} \mathrm{cfu} / \mathrm{mL}$ in milk from asymptomatic cows (Stabel et al., 2014). However, the number of MAP cells shed in milk by naturally infected cows showing clinical signs of Johne's disease (paratuberculosis), is estimated to be up to $1.32 \times$ $10^{3} \pm 3.1 \times 10^{2} \mathrm{cfu} / \mathrm{mL}$ (Stabel et al., 2014). As well, MAP has been be detected in contaminated feces at levels of up to $10^{8} \mathrm{cfu} / \mathrm{g}$ (Cocito et al., 1994), which can lead to high levels of contaminated milk. Accordingly, the pasteurization of MAP-contaminated milk used for calves can reduce the transmission of infection. Overall, contaminated milk cannot be excluded as a source of distribution. If the dairy herd becomes infected with MAP, it is advisable to avoid feeding MAP-contaminated milk. Regular examinations of milk samples, pasteurized or not, may help to prevent the spread of infection in a cattle herd.

In addition to milk-borne transmission, the spread of MAP into the farm environment via the washing water from the pasteurizer must also be considered. As the present study shows, disinfecting the pasteurizer was not an effective means of entirely inactivating MAP. Although very low amounts of MAP were measured, viable MAP cells were still detected and calculated in the rinsing and washing water of the pasteurizer by phage-based assay. Low cell numbers ranging from 2.11 $\times 10^{0}$ to $1.14 \times 10^{1}$ viable $\mathrm{MAP}$ cells $/ \mathrm{mL}$ in rinsing and washing water were found after milk containing $10^{4} \mathrm{MAP}$ cells $/ \mathrm{mL}$ was pasteurized. However, higher amounts of $3.89 \times 10^{0}$ to $9.78 \times 10^{3}$ viable MAP cells per $\mathrm{mL}$ washing water were found after pasteurization of milk containing $10^{7} \mathrm{MAP}$ cells $/ \mathrm{mL}$. Because these numbers were quite similar to those of pasteurized milk, these findings showed that the disinfection detergent we used was not effective in inactivating MAP. It has been documented that MAP remains viable and infectious for months outside the host in MAP-contaminated soil (Whittington et al., 2004). The pasteurization of milk with a high level of MAP contamination can therefore lead to a disturbance of the environment by releasing washing water. This is negligible in the case of direct infection, but probably leads to an accumulation of MAP in the farm environment.

We do not recommend feeding waste milk to newborn calves because of hygienic and veterinary concerns. However, given the results of the present study and findings from other studies, we can recommend that pasteurization of colostrum or milk become a standard on-farm procedure before feeding to suckling calves. This practice may promote a healthier herd by minimizing the risk of disease transmission.

In future, the effect of HTST pasteurization, including the newly developed steam-heating system, on colostrum quality and in particular on the composition of immunoglobulins, must be investigated, especially because Stabel et al. (2004) observed that colostrum pasteurization reduces the number of colostral immunoglobulins. Nevertheless, studies have indicated that feeding pasteurized colostrum instead of non-pasteurized colostrum to rearing calves results in better calf performance, lower mortality rates, and increased mean weight gain, conferring an economic advantage (Jamaluddin et al., 1996; Godden et al., 2005).

\section{CONCLUSIONS}

Although we detected a reduction in viable MAP cells in this study, MAP was able to survive pasteurization and can remain a problem in terms of transmission to young calves. However, in the case of waste milk feeding to calves, on-farm decontamination by pasteurization is highly recommended. Nevertheless, the distribution of paratuberculosis as a result of consuming pasteurized waste milk cannot be completely excluded. 


\section{ACKNOWLEDGMENTS}

The authors thank Martin Förster GmbH (Engen, Germany) for providing the pasteurizer used in this study. We are grateful to Lynne Barlow (Berlin, Germany) for completing the critical English language correction of this manuscript. The D29 bacteriophages and M. smegmatis laboratory strain $\mathrm{MC}^{2} 155$ were kindly provided by Irene R. Grant (Queen's University, Belfast, UK).

\section{REFERENCES}

Aust, V., K. Knappstein, H. J. Kunz, H. Kaspar, J. Wallmann, and M. Kaske. 2013. Feeding untreated and pasteurized waste milk and bulk milk to calves: Effects on calf performance, health status and antibiotic resistance of faecal bacteria. J. Anim. Physiol. Anim. Nutr. (Berl.) 97:1091-1103.

Ayele, W. Y., P. Svastova, P. Roubal, M. Bartos, and I. Pavlik. 2005. Mycobacterium avium subspecies paratuberculosis cultured from locally and commercially pasteurized cow's milk in the Czech Republic. Appl. Environ. Microbiol. 71:1210-1214.

Bickley, J., J. K. Short, D. G. McDowell, and H. C. Parkes. 1996. Polymerase chain reaction (PCR) detection of Listeria monocytogenes in diluted milk and reversal of PCR inhibition caused by calcium ions. Lett. Appl. Microbiol. 22:153-158.

Blome, R. M., J. K. Drackley, F. K. McKeith, M. F. Hutjens, and G. C. McCoy. 2003. Growth, nutrient utilization, and body composition of dairy calves fed milk replacers containing different amounts of protein. J. Anim. Sci. 81:1641-1655.

Bradner, L., S. Robbe-Austerman, D. C. Beitz, and J. R. Stabel. 2013. Optimization of hexadecylpyridinium chloride decontamination for culture of Mycobacterium avium ssp. paratuberculosis from milk. J. Clin. Microbiol. 51:1575-1577.

Brotherston, J. G., N. Gilmour, and J. M. Samuel. 1961. Quantitative studies of Mycobacterium johnei in the tissues of sheep: I. Routes of infection and assay of viable M. johnei. J. Comp. Pathol. Ther. 71:286-299.

Cocito, C., P. Gilot, M. Coene, M. de Kesel, P. Poupart, and P. Vannuffel. 1994. Paratuberculosis. Clin. Microbiol. Rev. 7:328-345.

Ellingson, J. L., J. L. Anderson, J. J. Koziczkowski, R. P. Radcliff, S. J. Sloan, S. E. Allen, and N. M. Sullivan. 2005. Detection of viable Mycobacterium avium ssp. paratuberculosis in retail pasteurized whole milk by two culture methods and PCR. J. Food Prot. 68:966-972.

Fechner, K., J. Schäfer, C. Wiegel, J. Ludwig, P. Munster, A. R. Sharifi, W. Wemheuer, and C. P. Czerny. 2017. Distribution of Mycobacterium avium ssp. paratuberculosis in a subclinical naturally infected German Fleckvieh bull. Transbound. Emerg. Dis. 64:916-928.

Foddai, A., C. T. Elliott, and I. R. Grant. 2009. Optimization of a phage amplification assay to permit accurate enumeration of viable Mycobacterium avium ssp. paratuberculosis cells. Appl. Environ. Microbiol. 75:3896-3902.

Foddai, A., C. T. Elliott, and I. R. Grant. 2010. Rapid assessment of the viability of Mycobacterium avium ssp. paratuberculosis cells after heat treatment, using an optimized phage amplification assay. Appl. Environ. Microbiol. 76:1777-1782.

Friedrich-Loeffler-Institut. 2014. Official Manual of Diagnostic Procedures. Vol. 2014. Friedrich- Loeffler-Institut, German Federal Research Institute of Animal Health, Greifswald, Germany.

Gerrard, Z. E., B. M. C. Swift, G. Botsaris, R. S. Davidson, M. R. Hutchings, J. N. Huxley, and C. E. D. Rees. 2018. Survival of $M y-$ cobacterium avium subspecies paratuberculosis in retail pasteurised milk. Food Microbiol. 74:57-63.

Godden, S. M., J. P. Fetrow, J. M. Feirtag, L. R. Green, and S. J. Wells. 2005. Economic analysis of feeding pasteurized nonsaleable milk versus conventional milk replacer to dairy calves. J. Am. Vet. Med. Assoc. 226:1547-1554.

Grant, I. R., H. J. Ball, S. D. Neill, and M. T. Rowe. 1996. Inactivation of Mycobacterium paratuberculosis in cows' milk at pasteurization temperatures. Appl. Environ. Microbiol. 62:631-636.

Harris, N. B., and R. G. Barletta. 2001. Mycobacterium avium ssp. paratuberculosis in veterinary medicine. Clin. Microbiol. Rev. 14:489-512.

Holsinger, V. H., K. T. Rajkowski, and J. R. Stabel. 1997. Milk pasteurisation and safety: A brief history and update. Rev. Sci. Tech. $16: 441-451$.

Jamaluddin, A. A., T. E. Carpenter, D. W. Hird, and M. C. Thurmond. 1996. Economics of feeding pasteurized colostrum and pasteurized waste milk to dairy calves. J. Am. Vet. Med. Assoc. 209:751-756.

Janagama, H. K., K. Jeong, V. Kapur, P. Coussens, and S. Sreevatsan. 2006. Cytokine responses of bovine macrophages to diverse clinical Mycobacterium avium subspecies paratuberculosis strains. BMC Microbiol. 6:10.

Klijn, N., A. A. Herrewegh, and P. de Jong. 2001. Heat inactivation data for Mycobacterium avium ssp. paratuberculosis: Implications for interpretation. J. Appl. Microbiol. 91:697-704.

Lambrecht, R. S., J. F. Carriere, and M. T. Collins. 1988. A model for analyzing growth kinetics of a slowly growing Mycobacterium sp. Appl. Environ. Microbiol. 54:910-916.

Lamont, E. A., J. P. Bannantine, A. Armien, D. S. Ariyakumar, and S. Sreevatsan. 2012. Identification and characterization of a sporelike morphotype in chronically starved Mycobacterium avium ssp. paratuberculosis cultures. PLoS One 7:e30648.

Mackintosh, C. G., R. E. Labes, R. G. Clark, G. W. de Lisle, and J. F. Griffin. 2007. Experimental infections in young red deer $(\mathrm{Cer}$ vus elaphus) with a bovine and an ovine strain of Mycobacterium avium subsp paratuberculosis. N. Z. Vet. J. 55:23-29.

Messelhäusser, U., P. Kämpf, S. Hörmansdorfer, B. Wagner, B. Schalch, U. Busch, C. Höller, P. Wallner, G. Barth, and A. Rampp. 2012. Culture and molecular method for detection of Mycobacterium tuberculosis complex and Mycobacterium avium ssp. paratuberculosis in milk and dairy products. Appl. Environ. Microbiol. 78:295-297.

Mumy, K. L., and R. H. Findlay. 2004. Convenient determination of DNA extraction efficiency using an external DNA recovery standard and quantitative-competitive PCR. J. Microbiol. Methods $57: 259-268$.

Münster, P., I. Völkel, W. Wemheuer, J. Petschenka, W. Wemheuer, C. Steinbrunn, A. Campe, W. J. Schulz-Schaeffer, L. Kreienbrock, and C. P. Czerny. 2011. Detection of Mycobacterium avium ssp. paratuberculosis in ileocaecal lymph nodes collected from elderly slaughter cows using a semi-nested IS900 polymerase chain reaction. Vet. Microbiol. 154:197-201.

Oliver, S. P., B. M. Jayarao, and R. A. Almeida. 2005. Foodborne pathogens in milk and the dairy farm environment: Food safety and public health implications. Foodborne Pathog. Dis. 2:115-129.

Rademaker, J. L., M. M. Vissers, and M. C. Te Giffel. 2007. Effective heat inactivation of Mycobacterium avium ssp. paratuberculosis in raw milk contaminated with naturally infected feces. Appl. Environ. Microbiol. 73:4185-4190.

Raizman, E. A., J. P. Fetrow, and S. J. Wells. 2009. Loss of income from cows shedding Mycobacterium avium subspecies paratuberculosis prior to calving compared with cows not shedding the organism on two Minnesota dairy farms. J. Dairy Sci. 92:4929-4936.

Rampling, A. M., M. H. Greenwood, and G. E. Davies. 2004. Use of a fluorimetric test for bovine alkaline phosphatase to demonstrate under-pasteurisation of skimmed milk and cream. Int. Dairy J. 14:691-695.

Selim, S. A., and J. S. Cullor. 1997. Number of viable bacteria and presumptive antibiotic residues in milk fed to calves on commercial dairies. J. Am. Vet. Med. Assoc. 211:1029-1035.

Sharma, R., and Y. S. Rajput. 2014. Rapid methods for assessing efficiency of heat treatment of milk. J. Food Sci. Technol. 51:14161420.

Shin, S. J., B. S. Lee, W. J. Koh, E. J. Manning, K. Anklam, S. Sreevatsan, R. S. Lambrecht, and M. T. Collins. 2010. Efficient 
differentiation of Mycobacterium avium complex species and subspecies by use of five-target multiplex PCR. J. Clin. Microbiol. 48:4057-4062.

Stabel, J. R. 2001. On-farm batch pasteurization destroys Mycobacterium paratuberculosis in waste milk. J. Dairy Sci. 84:524-527.

Stabel, J. R., L. Bradner, S. Robbe-Austerman, and D. C. Beitz. 2014. Clinical disease and stage of lactation influence shedding of $\mathrm{Myco-}$ bacterium avium subspecies paratuberculosis into milk and colostrum of naturally infected dairy cows. J. Dairy Sci. 97:6296-6304.

Stabel, J. R., S. Hurd, L. Calvente, and R. F. Rosenbusch. 2004. Destruction of Mycobacterium paratuberculosis, Salmonella spp., and Mycoplasma spp. in raw milk by a commercial on-farm high-temperature, short-time pasteurizer. J. Dairy Sci. 87:2177-2183.

Stabel, J. R., S. J. Wells, and B. A. Wagner. 2002. Relationships between fecal culture, ELISA, and bulk tank milk test results for Johne's disease in US dairy herds. J. Dairy Sci. 85:525-531.

Streeter, R. N., G. F. Hoffsis, S. Bech-Nielsen, W. P. Shulaw, and D. M. Rings. 1995. Isolation of Mycobacterium paratuberculosis from colostrum and milk of subclinically infected cows. Am. J. Vet. Res. $56: 1322-1324$

Sweeney, R. W., J. Uzonna, R. H. Whitlock, P. L. Habecker, P. Chilton, and P. Scott. 2006. Tissue predilection sites and effect of dose on Mycobacterium avium subsp. paratuberculosis organism recovery in a short-term bovine experimental oral infection model. Res. Vet. Sci. 80:253-259.

Sweeney, R. W., R. H. Whitlock, and A. E. Rosenberger. 1992. Mycobacterium paratuberculosis cultured from milk and supramammary lymph nodes of infected asymptomatic cows. J. Clin. Microbiol. 30:166-171.

Taylor, T. K., C. R. Wilks, and D. S. McQueen. 1981. Isolation of Mycobacterium paratuberculosis from the milk of a cow with Johne's disease. Vet. Rec. 109:532-533.

Whittington, R. J., D. J. Marshall, P. J. Nicholls, I. B. Marsh, and L. A. Reddacliff. 2004. Survival and dormancy of Mycobacterium avium ssp. paratuberculosis in the environment. Appl. Environ. Microbiol. 70:2989-3004.

\section{ORCIDS}

Jenny Teitzel $\odot$ https://orcid.org/0000-0003-1984-6295 